\title{
La judería de Úbeda en la Baja Edad Media
}

\author{
María Josefa Parejo Delgado *
}

\section{LOCALIZACIÓN GEOGRÁFICA}

La judería estuvo emplazada en el recinto del Alcázar según consta en el repartimiento de los pobladores de la collación de Santa María donde se dice:

«E Don Remon Diaz, donadio so las casas de Don Per Ibañez de... e sus casas fueron en el Alcázar e son agora judería...» «E Don Moro donadio entre las dos carreras que son a la torre de San Joan e en Olvera vinnas do el pozo de Domingo Leroño, sus casas que son del Cabildo de Santa María a la puerta de la judería cerca del adarve» ${ }^{1}$.

Así pues, hemos de localizar la judería cerca de las casas del Cabildo, teniendo como puerta propia cerca del adarve la históricamente conocida como Bahud o Abehud con su torre del mismo nombre. La arqueología ha proporcionado interesantes testimonios tales como una portada de fines del siglo xv en cuyo alfiz hay estrellas de David, situada en el callejón de Santa María, a espaldas del emparedamiento de Sancho Iñiguez; y en el fondo del patio de una casa de la Plaza de Carvajal un ventanal con arco lobulado de medio punto y decoración de tracería mudéjar, estrellas y la simbólica rueda del fuego persa. Según Vaño Silvestre la judería estaría situada en el terreno comprendido entre la parte trasera de Santa María y la actual Plaza de Carvajal, extendiéndose hacia la cuesta de este nombre hasta llegar a la muralla donde existe una puerta de arco de

* Doctora en Historia Medieval.

Parejo Delgado, M. J., Baeza y Úbeda en la Baja Edad Media, Granada 1988, Ed. El Quijote, págs. 178-180. CoRONAS TEJADA, L., Los judeoconversos en el reino de Jaén, BIEG, año XXIV, n. ${ }^{\circ} 97$, pág. 82. 
herradura protegida por torreón, de construcción almohade, ya citadas al describir la muralla, y que puede corresponder a la Puerta de Bahud.

Los rasgos generales de la judería son:

- Está defendida por los muros del concejo al ubicarse dentro del recinto amurallado.

- Tiene una división en calles bien visible y su propia toponimia.

En este sentido, la comuna judía es un espacio físico con calles propias como las de un concejo cristiano pero también dispone de un conjunto de instituciones religiosas y administrativas que permiten, gracias a la merced regia, al pueblo judío tener una identidad propia dentro de la sociedad cristiana y sujeta a las leyes generales del reino; dispone de una sinagoga, centro de la vida comunitaria por ser el lugar donde se administra justicia, escuela, templo y ayuntamiento. Otros edificios son las carnicerías, los mesones, posadas, baños, cementerios, hornos y lugares destinados a la fabricación del pan ácimo y del vino para sus ritos ${ }^{2}$.

Cabría preguntarse cuáles fueron los motivos de tal emplazamiento. Entre ellos podríamos indicar los siguientes: la necesidad de proteger a la comunidad judía de las iras del pueblo llano, la situación de protección de que gozan por parte de los grupos privilegiados, esencialmente la nobleza y la endogamia del grupo.

\section{LA ORGANIZACIÓN ADMINISTRATIVA Y JUDICIAL}

En Portugal, Castilla y Aragón el rabino mayor actúa como intermediario entre el soberano y los judíos. Tiene la confianza del Rey como financiero y físico. Representantes suyos son los «ouvidores" de las comarcas junto a los que hay un letrado o legista judío, bien conocedor del Talmud para la interpretación del derecho judaico. Tanto los oidores como el rabino mayor acostumbraban ir acompañados de un «porteiro» encargado de entregar, ejecutar las sentencias y cobrar las deudas. Por lo general un judío podía recurrir a tres instancias para seguir un pleito: el rabino de su comuna, el rabino mayor y sus oidores y el Rey. El derecho

Vaño SILVestre, R. y SánChes Fernández, E., Aportación al estudio del Alcázar de Úbeda, BIEG, año XXXI, pág. 25 m.s. 96. Academia de la Historia. Una más en apoyo de esta localización es una escritura de compra de unas casas en el alcázar «a junto con la sinagoga que fue de A Solomon o la Iglesia de Santa María. El comprador fue Ramón García Torpero y el precio 13.150 mrvs. (F. 70v-71r) actualmente hay restos arqueológicos de otra sinagoga junto a la Iglesia de Sto. Tomás. 
talmúdico es la base del juicio de los pleitos tanto civiles como criminales entre judíos y cristianos. En este sentido la comuna tiene una cierta autonomía jurídica sólo recortada por la Ordenación general del reino. Como jueces los rabinos tenían poder para multar, ordenar castigos corporales, e incluso lanzar excomuniones sobre sus correligionarios. En los casos de blasfemia contra la religión cristiana los judíos eran encerrados en la cárcel del concejo no en la judería ${ }^{3}$.

Una fuente de información esencial para el conocimiento de la organización administrativa y judicial de la aljama de Úbeda es el Fuero. El Fuero de Úbeda determina que los pleitos de los judíos con los cristianos sean juzgados por dos o cuatro alcaldes, judíos y cristianos. Si los judíos perdían el pleito eran castigados con la cárcel o el pago de una multa cuya cuantía estaba en relación al delito. Si el judío tiene algo empeñado la justicia le daba nueve días de plazo para quitar el empeño, sino tenía que pagar al juez diez maravedíes. Si un alcalde cristiano se niega a hacer justicia a un judío, éste debe exigírselo pero con un vecino cristiano. Los plazos para solicitar justicia en los pleitos que se produzcan entre judíos y cristianos se abrían a la hora de la misa matinal y se cerraban a la hora tercia.

Otros aspectos de la administración de la justicia que señala el Fuero son los casos de empeños, la negativa de un juez cristiano o judío a administrar justicia a judío o cristiano y los conflictos mixtos. Sólo los judíos que habían alcanzado la categoría de vecinos podían ser testigos. En los contratos entre judíos y cristianos, si se hacían empeños, el judío - el albedino debía quitarlos en nueve días si no perdía la cuantía del empeño y el albedino - juez judío - tendría que pagar al juez cristiano diez maravedíes.

Ahora bien, si un cristiano se querellaba con un judío y lo encontraba fuera de la "alcaicería» el dinero de las multas que el judío pague se las repartirán el juez y el querelloso. Si un juez cristiano no quiere hacer justicia a un judío pagará diez maravedíes al albedino. Si el judío es vecino podrá quedarse con las prendas o fianzas del acusado pero si no es vecino se las quedará el cristiano que lo acompañe. Si los alcaldes judíos no quieren administrar la justicia a un vecino cristiano, éste tomará la prenda en la casa del judío con un vecino judío, ahora bien si el cristiano es vecino las prendas serán para él, pero si no es vecino de la ciudad, las tendrá el judío con que prendare.

\footnotetext{
3 PImienta Ferro, M. J., Os judeus en Portugal no seculo XV. Lisboa 1982, Universidade Nova, págs. 108-109.
} 
El Fuero regula especialmente los conflictos mixtos entre judíos y cristianos. Así, por ejemplo, el judío o cristiano que tome los empeños o bienes puestos en garantía de pago sin mandamiento los devolverá a su dueño y pagará diez maravedíes al juez, querelloso y albedino.

Esta disposición tiene dos matices:

- Si el cristiano vecino no quiere ir con el judío querelloso a prendar pagará cinco sueldos, el albedino se quedará con los bienes empeñados o prendas y se repartirá la cuantía con el querelloso.

- Si el judío vecino no quiere ir con el cristiano querelloso a depositar las fianzas, pagará cinco sueldos, el albedino se quedará con las fianzas y las repartirá con el querelloso.

Otro caso jurídico que se plantea en el Fuero es cuando el cristiano no quiere ir a abrir la puerta de la casa de los empeños al judío, en este caso, el juez tomará las prendas y por cinco sueldos considerará las fianzas otorgadas como válidas, repartiéndose la multa con el querelloso. Si es un judio el qu'e se niega a devolver las prendas tomadas a un cristiano que las reclama, el albedino las tomará por cinco sueldos y considerará esas fianzas como suficientes. Si el juez cristiano no quiere ir con el judío pagará diez maravedíes al albedino y querelloso, y si es el albedino el que no quiere ir, pagará diez maravedíes al juez cristiano y querelloso. Los plazos para resolver los conflictos entre cristianos y judíos y recuperar los empeños se fijarán en la puerta de la alcaicería no de la sinagoga. Los judíos tendrán plazos según el Fuero excepto en Sábados y Pascuas. En las demandas, cuando la cuantía de éstas no supere los cuatro mencales, el judío podrá jurar sin átora y el cristiano sin cruz, pero si superan esta cantidad será necesario el juramento sobre átora en casos del judío, y sobre cruz del cristiano.

En las contiendas tanto los judíos como los cristianos deben presentar testigos que en el caso de los primeros deben ser cristianos. Si la contienda es por una cantidad inferior a los cuatro mencales basta con que los judíos presenten fianzas para ser creídos no precisando de testigos. Las multas por la infracción de esta norma son siempre el doble de la cantidad que es objeto de litigio. Los juicios que se celebren en la Cámara de los alcaldes serán firmes, ahora bien si el judío presenta fianzas y el cristiano quiere tomarlas conviene que demuestre las razones, ya que en caso contrario el judio no tendrá obligación de ofrecer prendas o bienes muebles y raíces como garantía. Si el cristiano no los desea puede entregarlos a un corredor que los venda y dé la ganancia al cristiano.

En cuanto a la justicia criminal los cristianos estarán obligados a pagar 500 sueldos al Rey si hieren o matan a un judío. En el caso de heridas, el cristiano debe probar el hecho con cuatro vecinos y en el de muerte 
con 12. Si es el judío el que hiere o mata a un cristiano pagará la multa establecida por el Fuero o podrá salvarse si demuestra con cuatro vecinos en el primer caso o con 12 en el segundo que lo hizo involuntariamente, ahora bien no dispondrá de ninguna parte en las multas establecidas, ya que el dinero de éstas será para el Rey puesto que los judíos son vasallos del Rey. En las deudas, la mujer e hijos de un judío responderán por las deudas del marido y padre si éste muere, en caso contrario, sólo deben pagar si se han hecho deudores pero no tienen esa obligación según el Fuero. En el apartado XIX se determina que ningún cristiano será preso por deuda a un judío ni lo prenderá otro por él. En el XXII se indica que cuando un judío reciba una paga de los cristianos tendrá que demostrarlo ante los testigos y dejar testimonio de lo que se le paga en carta de escribano, indicando lo que falta por pagar entre renglones en carta de deuda. Si un judío va contra ella pagará diez maravedíes, multa que se repartirán los alcaldes y el querelloso.

En las ventas el judío deberá admitir fianzas del cristiano fuera o dentro de la alcaicería, pagando el doble por ellos excepto si puede probar que lo hizo de acuerdo con un vecino cristiano entonces los tendrá libres. Si un cristiano quiere vender las prendas o bienes que le dé un judío los dará a un corredor que responderá ante el judío de las fianzas dadas, quedándose con un pequeño beneficio de la venta. En cuanto a la forma de jurar ante la justicia, el cristiano podrá hacerlo sin cruz cuando la cuantía de la demanda sea inferior a "cuatro mencales» y con cruz cuando sea superior. El judío sin átora en el primer caso y con ella en el segundo. La Torah es el Pentateuco o libro sagrado, más adelante fue el tributo pagado por cada familia judía, que coincidía con el barrio concreto de la aljama donde reside.

Un documento del Archivo Municipal de Úbeda de 1252 determina cómo han de jurar tanto los judíos como los cristianos y moros. Respecto a los primeros indican que deben poner la manos sobre el átora con la que hacen oración, jurar en nombre de Dios poderoso que hizo a Adán el primer hombre, al que le mandó que no comiese de la fruta, por el sacrificio de Abel, por Noé, por el Dios que salvó a Lot y a sus hijos, a Moisés, Josué, etc.

Otro documento de 1293 indica que a partir de esta fecha los alcaldes de las villas serán quienes libren los pleitos entre cristianos y judíos ${ }^{4}$.

4 Peset, J., El Fuero de Úbeda, tít. Lill. Valencia 1979, págs. 362-363. Rodríguez Molina, J., Colección diplomática del Archivo Municipal de Úbeda I. (s. XIII). Granada 1990, págs. 41 95. AMU 1252, junio, 21; AMU 1293 mayo, 25. Valladolid, caja 5, n. ${ }^{\circ}$. 
Igualmente está prohibido en Úbeda que los cristianos y judíos resuelvan sus pleitos con retos. En el caso de que los cristianos luchen contra los judíos y éstos últimos resulten heridos, los cristianos pagarán 500 sueldos al Rey o se salvarán con el testimonio de dos o cuatro vecinos, si los judíos mueren, los cristianos necesitarán 12 vecinos que testimonien a su favor para no pagar la multa al Rey. En ningún caso los judíos recibirán indemnización económica alguna, ya que son siervos del Rey. Algunos ejemplos de cómo el Fuero de Úbeda recoge las normas antes comentadas son: «E demas, sabida cosa sea que en Ubeda sobre judio vezino non a de firmar sinon judio e cristiano vezinos, nin sobre cristiano, sinon cristiano e judio vezinos. Mas las firmas entre cristiano e judio non rrespondan a rriepto."

«Sy el judio firiere al cristiano o matare, peche la calonna que fiziere al fuero de Ubeda. E si non, por la ferida saluese con doss de quatro connombrados judios e sea creydo. Mas por la muerte saluese con doze vezinos judios e sea creydo" ${ }^{5}$.

Según Peset, en sus comentarios al Fuero de Úbeda, los judíos son tratados aquí con amplitud y tolerancia; tienen su propio sistema de autoridades separados de la comunidad cristiana, se regula con cuidado los conflictos mixtos y la forma de solucionarlos, a diferencia de los territorios sometidos al Fuero de Toledo en que se someten al juez cristiano.

Eri 1304 Fernando IV al confirmar los privilegios a los judíos de sus reinos da una serie de normas para la administración de la justicia entre las que destacamos las siguientes:

1. ${ }^{a}$ Los cristianos que deban dinero a los judíos podrán pagarles con bienes raíces bien personalmente o a través de un entregador que podrá venderlos en 30 días para satisfacer la deuda. Si los entregadores no encuentran comprador de los bienes que se les dén a los judíos sin descuento alguno.

Con esta medida se trataba de limitar a los judíos el acceso a la propiedad de la tierra pero también protegerlos como siervos del Rey.

2. ${ }^{a} \quad$ Los judíos podrán demandar sus deudas a los ricos hombres y caballeros que estén cautivos en todo tiempo. Para ello deberán comunicar éstas a los alca!des entregadores de los lugares que se alzaron en tiempos de guerra.

5 Parejo Delgado, M. J., Baeza y Úbeda en la Baja Edad Media, ob. cit. Granada, págs. 179-180. 
3. ${ }^{a} \quad$ Cuando un judío sea preso de la justicia tendrá derecho a que se le guarden los privilegios y a una celda limpia pero sin pan ni agua.

Las Cortes de Valladolid de 1351 reducen un poco más la libertad de los judíos, ya que si bien tendrán un alcalde ordinario para sus pleitos, no podrán hacerles regalos y deben aguardar un plazo de seis meses para que los cristianos les paguen sus deudas.

En las Cortes de Toro de 1371 tras el triunfo de Enrique II Trastámara se perdona a algunas comunidades cristianas las deudas contraídas con los judíos y se da más valor al testimonio de un cristiano frente al de un judío. Esta actitud antisemita se consolida en las disposiciones judiciales y administrativas posteriores ${ }^{6}$.

\section{POBLACIÓN, SOCIEDAD Y ECONOMIA DE LA JUDERÍA UBETENSE}

Muy pocos son los datos que poseemos para evaluar cuantitativamente la población judía en Úbeda durante la época bajomedieval, ya que la contribución fiscal de ésta no siempre se correspondió a su población, por las numerosas franquezas de que gozaron los vecinos de Úbeda dada la situación "fronteriza" con Granada. De forma aproximada se puede indicar que teniendo en cuenta el número de familias que del reino de Jaén emigra al reino de Granada tras el pogrom de 1391 --unas 300 - y la población de Úbeda en 1407 unos 11.722 habitantes, los judíos no excederían del 2,5 por 100. El profesor Miguel Ángel Ladero Quesada trató de reconstruir el tamaño de algunas aljamas a partir del reparto de los pechos reales y concejiles. Según este profesor las contribuciones de los judíos eran de escasa monta, dentro del conjunto hacendístico castellano, y al quedar establecida su cuantía en una cantidad fija en maravedíes, que luego se repartía por encabezamiento entre las aljamas, su valor descendió.

Por su interpretación sabemos de la extrema dispersión de la población judía en Castilla durante el tercer cuarto del siglo $x v$ y de la relativa inestabilidad de los núcleos de la población judía, que se refleja en las fuertes oscilaciones en las cantidades pagadas. En el caso de Segovia, estudiado

6 Parejo Delgado, M. J., Baeza y úbeda en la Baja Edad Media, Letcom. Sevilla 1987, págs. 750-754. Romano Ventura, D., Marco jurídico de la minoría judía en la Corona de Castilla de 1214 a 1350. Actas del II Congreso Internacional Encuentro de las Tres Culturas. Toledo 1985, págs. 261-291. BAER, F., Historia de los judíos en la España cristiana. Madrid 1981. 
por la profesora María Asenjo, la aljama de Segovia era la de mayor volumen de población frente a las de su tierra, pasando de pagar 11.000 maravedíes a 1.500 .

Lo que significa que tan sólo Segovia, no su término, tendría una población superior a las diez familias. Los datos fiscales de úbeda nos indican como esta aljama pasó de contribuir con 25.000 maravedíes en 1291 a 19.390 en 1439 hecho que explica el retroceso demográfico. La relación de penitenciados de úbeda de 1494 -referida ya a conversos relajadosunos 208, del total de 331 que comprende úbeda y su término, y la población total para esta época entre 17.500 y 22.500 nos habla de un cierto retroceso de la población judeoconversa que supondría en el mejor de los casos entre un 0,6 y un 0,9 por 100 de la población total. Todas estas cifras son meramente aproximativas, ya que en el primer caso van referidos al reino de Jaén, y en el segundo aunque a la población judía de Úbeda que opta por convertirse y es después condenada por el Santo Oficio.

Respecto a la sociedad, la comuna judía refleja el esquema de la sociedad bajomedieval. Estuvo así, pues, dividida entre privilegiados y no privilegiados. Dentro del primer grupo hemos de citar a los arrendadores y recaudadores tanto de impuestos reales como concejiles, es el caso de don Samuel, almojarife de la Orden de Santa María de España y recaudador de las cosas en el reino de Jaén que vendió los bienes raíces y muebles de Pedro Navarro, por 100 maravedíes de la moneda de guerra «negocio del que yo fuy muy bien pagado» en tiempos de Alfonso X. La mayoría de los miembros de la judería desempeñaron trabajos artesanales, especialmente en el sector textil y mercantiles. El análisis del proceso inquisitorial de Fernado de Santistebán, mercader ubetense, nos indica cómo este comerciante, condenado por el Santo Oficio por hereje, era dueño de una haza de cereal, situada en Torreperogil, que fue entregada en dote a su mujer Beatriz Galán, por su padre don Alonso, propiedad que ésta vendió a los seis meses a Diego Fernández de Baeza y que tras el juicio celebrado contra él en 1523 determinó que el haza sería para el fisco real por haber sido condenado en 1482 Fernando de Santisteban a cárcel y confiscación de bienes y no ser correcta la venta. En el texto que seleccionamos se expone claramente los motivos que explican la invalidez de la venta.

«Item pongo y provar entiendo que el dicho Fernando de Santisteban fue condenado a la dicha carcel perpetua e todos sus bienes derechos e acciones confiscados por delito de la herejia que hizo e cometio anos a e mas tiempo e dende a esta parte fasta que fue condenado a carcel perpetua e a perdimiento de bienes e despues que fue hereje enageno la dicha haza de tierra perteneciente al dicho fisco real en perjuyzio suyo". 
«Iten pongo y provar entiendo que la dicha haza ha podido rentar e ha rentado en cada un anno... despues que asy yndebidamente la tiene ocupada el dicho Diego de Baeca regidor con mala fee sabiendo como sabia e sabe e syendo dello certificado que el dicho Fernando de Santisteban enageno e traspaso la dicha haza de tierra era y fue herege y por tal avido e tenido en la dicha cibdad de Ubeda mucho tiempo ha e tenia la dicha haza de tierra e lleuaua las rentas della...».

El proceso se inicia en 1510 cuando Alonso de Murcia, juez de los bienes confiscados del obispado de Jaén, recibe una demanda de Juan Sánchez de Venegas, teniente del receptor de los bienes confiscados en la que acusa al regidor Diego Fernández de Baeza de poseer una haza en el término de Torreperogil, que había comprado a Fernando de Santisteban, condenado por hereje hacía 29 años y que dicha propiedad era del fisco como la de todas las personas que habían sido condenadas a cárcel y confiscación. El juez recibe la demanda y otorga nueve días a Diego de Baeza para alegar lo que estime oportuno bien personalmente o a través de su procurador y le encarece a que se presente en las casas de la Inquisición de Jaén. El notario Antonio de Galdiano comunica la demanda a Diego Fernández de Baeza. El 9 de octubre de 1510 Juan de Fregenal, procurador de Diego Fernández de Baeza presenta un poder por el que su representado le autoriza a realizar las probanzas y alegaciones que sean necesarias. El juez lo acepta y le indica que alegue lo que estime oportuno. Juan Frenegal niega la demanda «en todo y por todo" y pide su anulación. Más tarde Rodrígo Mexía, teniente del receptor, reclama la presencia física de Diego Fernández de Baeza pero Juan de Fregenal dice que es viejo y que venir a la ciudad de Jaén causaría un grave quebranto para su salud. El juez le pide que presente testigos que avalen su incapacidad para viajar y Juan Frenegal requiere los testimonios de Luis de Vago y de Gerónimo de Pareja que indican que Diego Fernández es viejo de 60 ó 70 años que está enfermo de gota y que no puede venir cabalgando hasta Jaén. El 10 de octubre de ese mismo año el juez Alonso de Murcia pide a Rodrigo Mexía que presente sus testigos ante el notario, ya que le consta que el delito no es tan grave y que él debe ocuparse de otros asuntos más importantes. Ese mismo día Rodrígo Mexía presenta varios testigos: Alonso de Guzmán, Diego Fernández de Andújar, Francisco de Molina y Cristóbal de Molina, que exponen que Diego Fernández puede venir cabalgando a Jaén porque si bien es viejo, ellos lo han visto a caballo por sus posesiones. El 16 de octubre de ese mismo año Rodrígo Mexía, teniente del receptor, pide al juez que Juan Fregenal, procurador de Diego Fernández de Baeza, lo traiga personalmente para jurar de calumnia. Diego Fernández de Baeza presenta un escrito ante el corregidor de Baeza y úbeda en el que expone que no 
puede ir a Jaén por estar enfermo. Juan Fregenal presenta el escrito ante el bachiller Alonso de Murcia, juez, en el que se indica que la demanda no procede, pues su demandado compró la haza hace treinta años en 1480 y que dicha propiedad la había recibido en dote Beatriz Galana al casarse con Fernando de Santisteban. A continuación expone que «ltem sy saben que al tiempo que los susodichos casaron desde quatro o cinco annos que se reconciliaron en esta cibdad tenían pocos byenes y fysieron ynventario de cincuenta mil mrs. y pagaron doze mil mrs. que les fueron ympuestos de penitencia». Diego Fernández indica que la haza no era toda de Fernando de Santisteban, sino de su mujer Beatriz y que aunque él fuera reconciliado ella no podía perder los bienes de su dote como lo indican las leyes dadas por Sus Altezas. Igualmente dice que Fernando de Santisteban era tenido por buen cristiano en Úbeda y no por hereje.

La información que proporcionan los testigos de Diego Fernández de Baeza sobre la propiedad son de gran interés para conocer la evolución de la propiedad y la mentalidad de los conversos respecto a la tierra. Los testigos dicen que la haza la compró Diego Fernández de Baeza a Beatriz, mujer de Fernando de Santisteban hace 30 años por 40 arrobas de lana que son unos 10.000 maravedíes y continúan «ltem sy saben que al tiempo que la dicha Beatriz vendyo la dicha haca al dicho regidor fue para utilidad suya ya que ella y el dicho su marido con su yndustria y mercaduria multyplicaron muchos bienes en contia de doscyentos mil mrs que tovieron en posesyon fasta que puede axer anno e medio que prendieron a Fernando de Santisteban».

A partir de este momento la hacienda de Fernando de Santisteban se vio mermada por la condena inquisitorial pues el Inventario que se les hace tras ser reconciliados indica que sólo tenían unos 50.000 maravedíes; cantidad que refleja no obstante que su estatuto si bien no es equivalente al de la nobleza sí al de muchos mercaderes y artesanos ubetense enriquecidos a fines del siglo $\mathrm{XV}$ con la compraventa de tierras y casas según acreditan los contratos de este tipo que se encuentran en los Fondos de Protocolos de Úbeda.

En nuestra consulta al Archivo de Protocolos de Úbeda hemos encontrado algunas noticias referentes a algunos de los penitenciados de 1496 en su día estudiados por el profesor Ladero Quesada. La información en ellos contenida nos indica cómo hay un cierto número de conversos propietarios o arrendatarios de pequeñas y medianas propiedades agrícolas. Así, por ejemplo, una carta de arrendamiento de 1507 nos indica cómo Rodrigo de Castro, mercader, penitenciado número 184 de Úbeda en 1596, tenía en arrendamiento la mitad de una huerta con agua y rueda en la vega, linde con las tierras de Diego Mexía, regidor y las de Ber- 


\section{UBEDA \\ Judería}

E7?

$\Rightarrow 2=2$

15

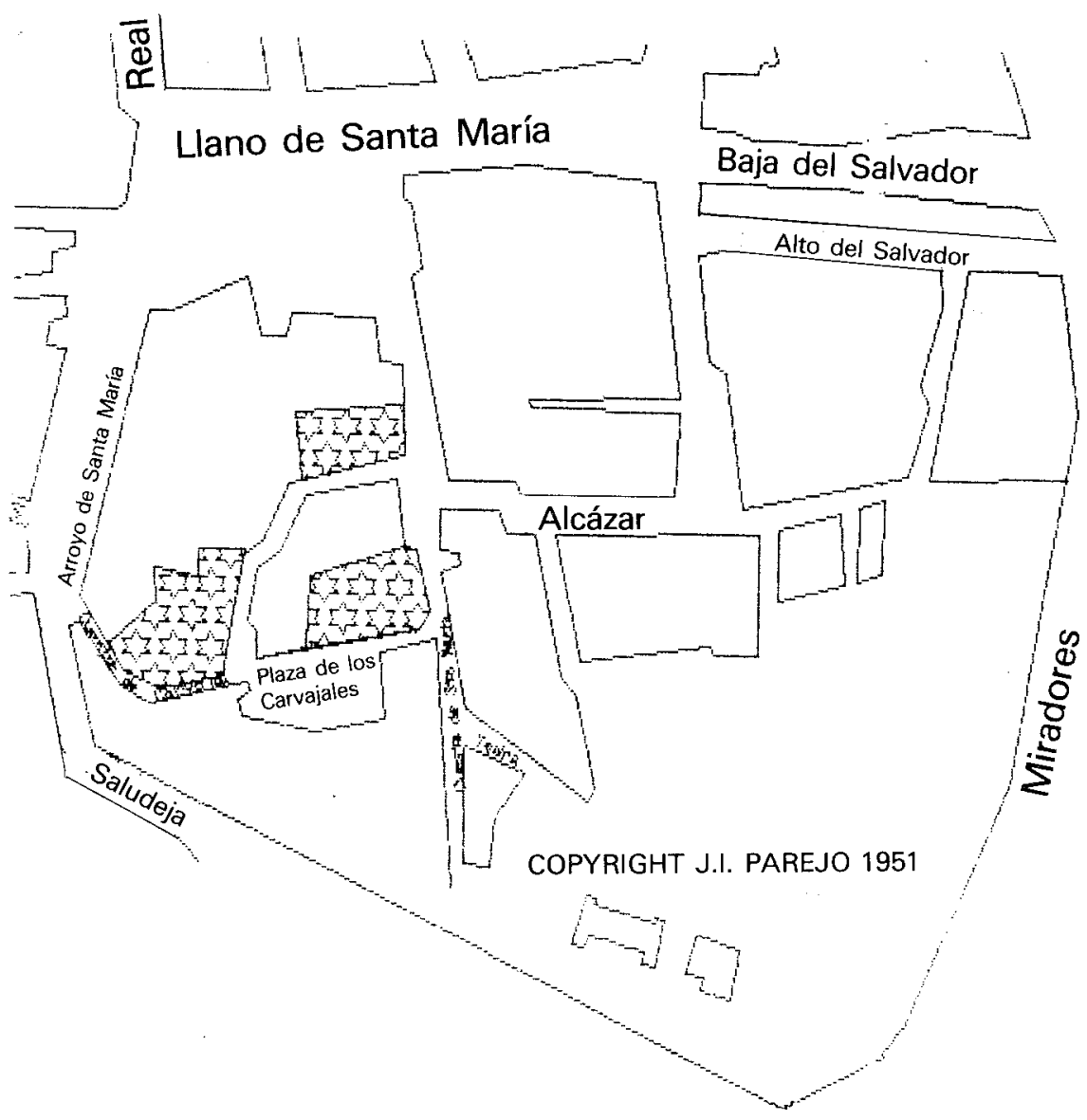

Fig. 1. Judería de Úbeda 
naldino de Quesada. Se trata de un contrato por cinco años en el que Pedro Gutiérrez de Quesada y su hijo deberán pagar 1.500 maravedíes anualmente repartidos en tres plazos por San Miguel. La carta de dote de María Alonso, penitenciada número 109 junto a su marido Juan Mercader, recibe al casarse dos eriazos de 800 maravedíes, dos majuelos en San Ginés y el Barranco de 4.000 maravedies y tres hazas por valor de 15.000 maravedíes. La carta de dote de Isabel Rodríguez, penitenciada número 201 de Úbeda, indica que recibe al casarse un majuelo de 600 vides. Fernando de Baeza, penitenciado número 74, vende en 1519 un majuelo de viñedo de Jaén de 400 vides en la Huerta Nueva a Juan Delgado, oficial del barro de la ciudad por 2.000 maravedíes.

Por último la carta de dote de Catalina Gómez en 1493 nos informa de cómo recibe al casarse cinco hazas, una suerte de 13 olivos, un majuelo de 300 vides de vino tinto y otro de 563 vides. Se observa claramente cómo muchos judíos al convertirse gozan de una relativa posición económica, bastante similar a la de muchos artesanos, comerciantes y medianos labradores de la ciudad. Igualmente se constata cómo al ser condenados sufren una importante merma económica, ya que las condenas más numerosas son las pecuniarias e igualmente se constata la estrategia utilizada por los conversos de alegar que los bienes que venden corresponden a las dotes de sus mujeres para garantizar la legalidad de sus operaciones financieras.

La mayoría de los miembros de la judería de Úbeda desarrollaron actividades muy similares a las de los cristianos, destacando especialmente el comercio, la orfebrería en oro y plata, el trabajo del tinte y de los metales, el cultivo de la tierra, la medicina y en algunos casos el arrendamiento de los impuestos reales y el crédito.

Una disposición de 1293, en la que Sancho IV confirma los privilegios a los vecinos de la ciudad de úbeda, ordena que los judíos no puedan comprar heredades y que los que tengan ahora los vendan en un año a quien quiera comprárselos, en caso de no encontrar comprador para sus heredades deben entregarlos a los alcaldes del lugar para que los valoren y vendan en un año, permitiendo a los judíos sacar los bienes muebles que tengan en sus heredades. Esta disposición explica cómo algunos judíos como el almojarife Samuel venda sus bienes raíces a Pedro $\mathrm{Na}$ varro, morador de la collación de Santa María de Úbeda; bienes que había recibido tras la reconquista y repartimiento de tierras de la ciudad. En 1304 Fernando IV limita los derechos de los judíos al acceso a la propie- 
dad de la tierra, ya que les permite cobrar sus deudas en dinero no en bienes raíces ${ }^{7}$.

Más flexible es la normativa fijada en las Cortes de Burgos de 1367 en la que se obliga a los judíos a pagar impuestos por las heredades que compren a los cristianos, hecho que demuestra que durante el reinado de Pedrol se permite a esta minoría adquirir heredades a cambio del pago de una serie de impuestos sobre ellas, necesarios para costear la política social y belicista del Rey. Una disposición de 1350 permite a los judíos comprar heredades hasta de cierta cuantía. Estas medidas permisivas son consecuencia de la influencia de Samuel Levi en la política económica castellana, del apoyo del Rey a la comunidad judía frente a las pretensiones nobiliarias y de las acuciantes necesidades económicas de la Monarquía. Las disposiciones de las Cortes de 1377 si bien limitan a los judíos la posibilidad de comprar grandes herededades, permiten hacer cartas de obligación sobre vino, cera, etc. En Portugal existe limitaciones similares respecto al acceso de los judíos a la propiedad de la tierra excepto en el caso del viñedo, cuyo diezmo cobra el Rey ${ }^{8}$.

La existencia de un sector agrícola en la comunidad judía de Úbeda queda perfectamente testimoniada, ya que en 1494 en la relación de penitenciados de la Inquisición de dicha ciudad el 57 por 100 son labradores.

La actividad mercántil es la ocupación principal de la comunidad judía. La profesora María José de la Pimienta estima que el hecho de que muchos judios fueran los banqueros de los Reyes en Portugal llevó a éstos a una política mercantilista para evitar el drenaje de oro y plata a Castilla, así como a limitar el ejercicio de determinadas profesiones a los extran-

A.R. Chancillería de Granada, cabina 201, sec. Inquisición, leg. 5.180 , pieza $n .^{\circ} 3$, fols. 1 14v. Parejo Delgado, M. J., Baeza y úbeda..., ob. cit. Sevilla, págs. 753-755. Grupos urbanos no privilegiados de Úbeda y Baeza en la Baja Edad Media, Actas del III Coloquio de Historia Medieval Andaluza. Jaén 1984, págs. 165-177. Archivo de Protocolos de Úbeda. Carta de venta de Francisco de Cazorla, curtidor, leg. 1.011, 31-12-1519; Cartas de arrendamiento de Diego de Quesada, leg. 766, 1-11-1514; Cartas de arrendamiento de Pedro de Cazorla, leg. 766, 5-71508; Cartas de dote de María Alonso, leg. 766, 17-1-1503 e Isabel Rodríguez, leg. 766, 1-1506; Carta de arrendamiento de Rodrigo de Castro, mercader, leg. 1.279 a 23-2.-1507; Carta de venta de Fernando de Baeza, leg. 1.011, 31-12-1519.

a Montes Romero-Camacho, 1., La minoria hebrea sevillana a fines de la Edad Media, V Coloquio Internacional de Historia Medieval Andaluza. Córdoba 1988, págs. 551-568. Hace un análisis de la organización judicial y de la distribución de la población judía por sectores productivos. Cantera Montenegro, E., Actividades socio-profesionales de la mujer judía en los reinos hispanocristianos de la Baja Edad Media. El trabajo de las mujeres en la Edad Media hispana. Madrid 1988. En este artículo se recogen las distintas profesiones ejercidas por la mujer judía. En nuestro caso la documentación es muy pobre aunque el Fuero de Úbeda nos habla de nodrizas judías a las que se les prohíbe amamantar a un niño cristiano, prostitutas y arrendadoras de tierras, págs. 321-345. 
jeros dando primacía a los naturales del reino. En Úbeda tenemos constancia de un grupo de mercaderes dedicados al comercio interior de telas, vino, e incluso esclavos. En la relación de penitenciados de 1494 el 12 por 100 son mercaderes, destacando a Alonso Gómez, Fernando de Baeza, Diego de Córdoba, Diego López de Benavides entre otros. En 1489 todavía hay constancia de judíos comerciantes como Natan Narboy y el rabino Abraham, físico del adelantado, quien pide que las ciudades desde úbeda a Medina no cobren derechos por el traslado de su cuerpo.

La artesanía textil, la herrería y la medicina son otras profesiones desempeñadas por los judíos ubetenses. En el primer sector destacan los curtidores, los sastres y los tejedores, en el segundo los fabricante de armas y herramientas agrícolas y finalmente los físicos y boticarios. Un 35 por 100 de los penitenciados de Úbeda de 1494 son trabajadores del sector secundario. Uno de ellos, Luis de Cazorla, tundidor, penitenciado número 141, hijo del condenado Diego de Cazorla, tintorero, penitenciado número 51, es hermano de Francisco de Cazorla, curtidor y pequeño propietario agrícola como lo testimonia la venta que hace en 1519 a otro curtidor Martín García de un majuelo de 160 vides tempranas en el pago de Nalda, linde con el olivar de Hernando Hidalgo, calderero por 800 maravedies.

Quizás la actividad más conocida, pero ejercida por una minoría de privilegiados dentro de la judería, es el arrendamiento de impuestos reales y concejiles. En este sentido el Archivo Municipal de Úbeda nos ilustra con varios ejemplos. En el siglo XIII destaca don Samuel, almojarife, vecino de Úbeda, quien aparece en la documentación vendiendo unos bienes porque el propietario había muerto sin comparecer heredero ninguno y pasó el plazo que manda el Rey. En 1336 dos judíos, Simón Iñiguez y Fraimen Aben Verga, son los arrendadores de la alcabala del vino de Baeza. Años más tarde don Abraham Yaex es nombrado arrendador de la renta de la escribanía pública de Baeza y don Moya Abeb Amices y don Cas Abel Atabab son los arrendadores de la alcabala de Bailén. No obstante, la legislación restrictiva de la monarquía castellana durante el siglo xv limita el ejercicio de esta actividad a los judíos por lo que son en 1494 tan sólo hay un 2,3 por 100 de los penitenciados que han ejercido esta profesión ${ }^{9}$.

9 Parejo Delgado, M. J., Baeza y Úbeda..., ob. cit., Sevilla, págs. 750-752, 762. En el Fuero de Úbeda, pág. 399, se hace referencia a como se descuenta a Adan Moyr Aben Megas del almojarifazgo de Córdoba por la franqueza que el Rey hizo a los de Úbeda de 814 maravedís y dan a Don Yucaf Aben Caparici e Adan, 204 maravedís del diezmo del aceite y le descuentan del almojarifazgo de Jaén por la franquicia de Úbeda 860 maravedís por testimonio de García Pérez, alcalde de la aljama de Jaén. La relación de penitenciados la incluimos en las págs. 765779. Pimienta, M. J., ob. cit., págs. 297-313. 


\section{TRIBUTOS, ENCARGOS Y SERVICIOS}

La protección real sobre los judíos no es gratuita, ya que es una de las fuentes de rendimiento del soberano como sus tributarios. La presión fiscal sobre la comunidad judía recae en un doble sentido, los derechos reales y las tallas. El servicio real, las sisas y encabezamientos son más gravosos para los judíos que para los demás cristianos y se dedican a costear la guerra, bodas reales defensa o superar momentos de dificultades económicas. Las tallas son exigidas por las autoridades concejiles para la conservación de la muralla de la ciudad, pagar los procuradores que asisten a las reuniones de las cortes, arreglo de vías y calzadas y de fuentes públicas.

El servicio es recogido por cabeza sobre los bienes muebles y raíces, mercancías y compra y venta de artículos excepto los libros, la vivienda y los animales de trabajo. En Portugal pagaban cinco sueldos los hombres menores de siete años, 20 los de más de 14 años que viviesen de su trabajo y las mujeres la mitad. En el siglo XV los procuradores de las comunidades judías se reunieron en Asamblea General para dividirlo por las cabezas de las comunidades, correspondiendo a cada una de ellas una cuantía equivalente a su densidad de población y riqueza. Después se repartiría por aljamas.

La comunidad judía de Úbeda pagaba varios tributos:

- La cabeza de pecho o cantidad anual que cada hebreo tributaba en reconocimiento del señorío y protección real.

- El servicio y medio servicio tributado en las juderías por el sistema de capitación y cobrado en el siglo xv a partir de un montante fijo.

El primer impuesto aparece en la documentación hacia 1439 y deja de ser citado en 1448 bien por su escaso valor o porque no se cobraba. En todo caso hay que relacionarlo con un descenso demográfico en la judería de Úbeda que en 1291 tributaba unos 25.000 maravedíes y en 1439 unos 19.390 maravedíes ${ }^{10}$.

Sabemos poco de los impuestos municipales con que contribuían los judíos dentro de la ciudad. En úbeda los judíos vecinos pagan sisas sobre la carne y el pescado y participan en las derramas concejiles impuestas en los momentos de necesidad financiera, también contribuyen en la cons-

\footnotetext{
10 Pimienta, M. J., ob. cit., págs. 159-161. Parejo Delgado, M. J., Baeza y úbeda en la Baja Edad Media. Sevilla 1987, Letcom. pág. 759. Ladero Quesada, M. A., «Los judíos castellanos del sigloxV en el arrendamiento de los impuestos reales", Cuadernos de Historia, VI, 1975, págs, 417-439.
} 
trucción de puentes y fuentes. En Portugal por costumbre más que por ley participan en algunas empresas militares como Arcila y Ceuta, aunque estaban exentos de este servicio y pagaban a la iglesia las primicias y diezmo de sus propiedades rurales. La profesora María José de la Pimienta ofrece varias explicaciones al respecto; que la mayoría de las propiedades regias arrendadas por los judíos no pagan diezmo a la iglesia, que esta imposición es sustituida por la entrega del diezmo de la producción al Rey, y que el diezmo de la iglesia recae sobre los bienes raíces alquilados o comprados a los cristianos ${ }^{11}$.

En Úbeda pagaban el tributo de las 12 monedas según un documento del Archivo Municipal en dos plazos de seis monedas cada uno. Ningún vecino ni judío ni cristiano, pechero o hidalgo, podía eximirse, quedando sujeto a la pérdida de sus bienes por confiscación. Este impuesto se cobraba a partir de un padrón confeccionado por los alcaldes y oficiales de la villa para su correcta recaudación. Es posible aventurar una cierta relación con el tributo de los 30 dineros por cabeza que según la profesora María Asenjo pagaban los judíos de Segovia y que obligaba igualmente a la comunidad cristiana. También con el simbolismo del 12 -las 12 tribus de Israel- para los judíos. Una disposición de las Cortes de Burgos de 1367 se obligó a pagar los derechos o pechos por la compa y venta de las heredades a los cristianos $^{12}$.

Las Actas Capitulares de Úbeda de 1462 mencionan un pedido realizado a la aljama de los judíos en 1462 con motivo de la guerra contra Granada. Se piden 86 cuantías a pagar la primera mitad en ese año y la segunda en el siguiente, si no fuese suficiente, lo que faltara por pagar se haría en los dos años «venideros". El primer pago se realizaría los días 8 de agosto y 8 de diciembre de 1462 y el correspondiente a 1463 el 8 de marzo y el 8 de junio. La cuantía del tributo dependería de la hacienda de cada vecino. Así los que tuvieran bienes por valor de 60 maravedíes en bienes muebles o raíces contribuirían con una moneda, los de 120 maravedíes con dos, los que tuvieran hacienda por valor de 160 con cuatro monedas y así sucesivamente hasta llegar a los que tuvieran bienes por valor de 280 maravedies que pagarían ocho monedas.

11 Pimienta, M. J., ob. cit., págs. 192-193.

12 Asenjo Serrano, M., Segovia la ciudad y su tierra a fines del Medievo. Segovia 1986, págs. 322-326. El número de conversos de Segovia en 1510 es de 209 familias, un total de 788 personas. En Úbeda por la relación de penitenciados que sólo da una idea aproximativa hay unos 331 en el término y 208 en la ciudad. Parejo Delgado, M. J., Baeza y Úbeda en la Baja Edad Media. Sevilla, pág. 760. 
Otro documento de 1492 (Archivo Municipal de Úbeda, Legajo 5, núm. 48), obliga a los judíos a pagar los derechos de todas las mercaderías que adquieran, indicando que sólo pueden eximirse los vecinos cristianos. La multa en caso de infracción sería de 10.000 maravedíes.

«Don Fernando e Donna Ysabel rey e reina... a vos los gobernadores de las ciudades de Guadix e Baza... a e a vos a quien mi carta fuere mostrada. Sepades que nuestro arrendador real de las rentas de estas ciudades e su partido... nos fue fecha relacion de que los judíos e moros se excusan de no pagar los derechos de las mercaderías que tratan e sacan de las dichas ciudades en razón e franqueza de los cristianos e que piden que no sean francos los dichos judios e moros porque por ello resciben mucho agravio e danno... Por lo que os pido poner remedio... e mandamos que proveais que los dichos judios e moros que traigan mercaderias e ganados a estas ciudades paguen al recaudador mayor los dichos derechos que deben.... ${ }^{13}$.

\section{LA CONVIVENCIA ENTRE JUDÍOS Y CRISTIANOS EN LA ÚBEDA BAJOMEDIEVAL}

En el Fuero de Úbeda de 1269 aunque los judíos disponen de sus propios alcaldes y puede hablarse de una cierta tolerancia inicial, los judíos no pueden tener relaciones con mujeres cristianas, vender cro, plata y armas, ir al baño los mismos días que los cristianos y tienen ciertas restricciones jurídicas.

Así, por ejemplo, para exigir justicia deben hacerlo con un cristiano, no pueden recibir por deudores a la mujer e hijos de los cristianos y en caso de lucha, si gana el judío no recibirá parte de las multas que irán al Rey, ya que son siervos del Rey.

Estas disposiciones legislativas están en relación directa al espíritu de las Decretales donde se prohíben los casamientos mixtos entre judíos y cristianos y el ejercicio por éstos de cargos públicos. El judío tiene una personalidad jurídica reducida ya que su testimonio sólo vale si es corroborado por el de un cristiano. Tanto el Concilio de Letrán de 1215 como las Cortes de Elvas en Portugal determinan que llevan vestidos, peinados diferentes, una cruz amarilla como distintivo y que vivan en barrios separados. En el Fuero de Úbeda se prohíbe que las mujeres cristianas amamanten niños judíos y al revés.

13 AMU, leg. 5, n. ${ }^{\circ} 48,1492$. 
El castigo con que se penalizan las relaciones sexuales entre cristianos y judías es el de la pena de muerte, de ahí la endogamia. En 1304 Fernando IV establece nuevas normas jurídicas para la comunidad judía, así, por ejemplo, se fijan los plazos para que los cristianos puedan pagar las deudas a los judíos, se facilita el cobro de éstas en dinero pero se dificulta el acceso de los judíos a los bienes raíces y muebles. Se permite a los judíos demandar las deudas que tengan de los ricos-hombres y caballeros que estén cautivos en Granada y se facilita que éstos presenten sus demandas ante los alcaldes del lugar donde viven con cartas de escribano. Así pues a comienzos del sigloxIV, aunque la iglesia los ve como los homicidas de Cristo, han sido expulsados de Francia e Inglaterra y las disposiciones del Concilio de Zamora de 1312 les prohíben ejercer determinados cargos, ser testigos, ejercer la medicina y practicar la usura, la monarquía castellana de Alfonso XI los usa como almojarifes como don Yucaf de Écija.

Este Rey permite que algunos judíos desempeñen funciones mercantiles como Simón Iñiguez y Aben Berga, recaudadores de la alcabala del vino en 1336, arrienden la renta de la escribanía pública de Baeza en 1343, que estuvo durante 13 años en manos de don Abraham Yaex de Toledo con objeto de recoger dinero para pagar a los ballesteros y caballeros que fueron al cerco de Algeciras ${ }^{14}$.

Los Anales de la villa de Arjona de Martín de Ximena Jurado nos indican la existencia de un pogrom en esa villa hacia 1349. Las causas del mismo son la denuncia que el concejo de la villa formuló contra el arrendador de las rentas reales don Yucaf Ibrahim a causa de los abusos que cometía en la cobranza de éstas. El tesorero real Miguel Ruiz testimonió a favor del judío, lo que provocó fuertes protestas populares en la villa. Las malas cosechas y la epidemia de peste que azotaron a los vecinos de Arjoja los años anteriores dejaron a la población hambrienta, desnutrida y enferma, a lo que se une la durísima presión fiscal que levanta las iras de los vecinos contra los judíos ante la pasividad de las autoridades concejiles. Alfonso XI, informado de los hechos, resolvió confiscar los bienes y haciendas de los vecinos y enviarlos a servir durante cuatro meses a su Real de Gibraltar. La despoblación de la villa obligó a Pedrol a reconsiderar la decisión y otorgarles el perdón en 1350.

\footnotetext{
14 Pimienta, M. J., ob. cit., págs. 397-399. Parejo Delgado, M. J., ob. cit., Sevilla, págs. 743-749; El reino de Jaén en la Baja Edad Media según los Anales de Martín de Jimena Jurado. Sevilla 1977, en prensa, págs. 322-332. Mozo y ORTIz DE VILLAJOS, S., "Los judíos castellanos en el reinado de Alfonso XI», Sefarad, XXXV, 1975, págs. 131-150 y XXXVI, 1976, págs. 37-120.
} 
El Ordenamiento de Alcalá de 1348 recorta algunos de los privilegios de los judíos al reducir una cuarta parte de la deuda que los cristianos deben pagar y prohibir el préstamo a interés. Son años de un cierto fortalecimiento de la comunidad judía, ya que son muy numerosos los judíos arrendadores de impuestos reales y concejiles. La documentación de Úbeda nos indica algunos ataques a las juderías de Arjona y úbeda ante los abusos del almojarife don Yucaf. La protección que les dispensa Pedro I frente a las pretensiones nobiliarias y las agobiantes necesidades financieras de la Corona castellana por su lucha contra Aragón contribuyen a esclarecer esta oleada antisemita. La hacienda regia estará controlada por Samuel Levi. Esta influencia de los almojarifes judíos se observa en el acaparamiento de algunas rentas por los hebreos, es el caso de don Moya Aben Amias y don Cas Abel Atabab, arrendadores de la alcabala de Bailén, señorío de Pedro Ponce de León. En las Cortes de Valladolid de 1351 se obliga a los judíos a vivir en lugares apartados tras las revueltas de 1348 , asimismo se les prohíbe practicar la usura, tener nombres cristianos, vivir como ellos, y criar a sus hijos, imponiendo fuertes multas en dinero y azotes a los infractores. Se dan facilidades a los cristianos -hasta seis años de plazo- para pagar las deudas a los judíos. Pese a todo, los judíos pueden comprar heredades hasta cierta cuantía, con ello se trata de evitar que formen grandes señoríos, se les permite alquilar casas pero sin pujar a alza y de nuevo disponen de un alcalde para sus pleitos. Esta armonía entre judíos y cristianos se debe a la militancia de los primeros en el bando petrista, más tarde las malas cosechas que agravan la presión fiscal de los labradores se ven obligados a solicitar un aplazamiento en el pago de sus deudas, las epidemias de peste de 1348-1351 y 1363 y la victoria de Enrique II Trastamara agravan la situación de los judíos. En esos momentos se produce una crisis en la comunidad judía entre un grupo de privilegiados, defensores del deísmo y otro de comerciantes, que piensan es necesario una reforma moral. La necesidad de aislar a la comunidad judía, según Valdeón en plena pujanza económica y demográfica para evitar el proselitismo, las protestas de las Órdenes mendicantes por la ocupación de los judíos de cargos jurisdiccionales y financieros y los abusos cometidos contra el Común por el excesivo interés de los préstamos preparan el terreno para la intolerancia.

Los asaltos a las juderías cometidos durante la guerra civil entre $\mathrm{Pe}$ dro I y Enrique II cuyas tropas destruyeron algunas juderías portuguesas obligaron a algunos judíos a emigrar a Granada - unos 300 - o a convertirse $^{15}$.

15 Parejo Delgado, M. J., Baeza y Úbeda en la Baja Edad Media. Sevilla, págs. 750-758. 
El triunfo de Enrique II en la guerra fue el antijudaísmo así, por ejemplo, en las Cortes de Toro de 1371 se permite que algunas comunidades cristianas no paguen sus deudas a los judíos, se les obliga a vivir en sus propios barrios, con señales y nombres propios. En las Leyes de Burgos de 1377 se perdona a los cristianos la tercera parte de las deudas contraídas con los judíos y se les permite pagar a plazos las otras dos. En 1379 se prohíbe a los judíos privilegiados que tengan guardado aquello que encontraren. La presión popular y la necesidad de legitimar el gobierno impuesto por la fuerza de las armas llevó a dar nuevas normas de marginación de los judíos, obligándoles a vivir en barrios separados, prohibiéndoles decir palabras injuriosas contra la religión cristiana y limitando sus prácticas religiosas como la circuncisión.

Estas medidas antisemitas no impiden que la monarquía siga nombrando recaudadores judíos para el efectivo funcionamiento de la $\mathrm{Ha}$ cienda. Por ello en 1391 cuando se produce la conjunción de epidemias, malas cosechas, sequías, las predicaciones de Ferrán Martínez, arcediano, de Écija, que justifica la destrucción de las sinagogas como casas del diablo, el antisemitismo, recrudece y se suceden los asaltos a las juderías de Sevilla, Córdoba, Jaén, Baeza y Úbeda. No obstante, la iglesia, la nobleza y el Consejo de Regencia no castigan a los culpables ya que se benefician de los bienes de los judíos. Las consecuencias del pogrom fueron la redistribución de la población judía en los concejos andaluces, la emigración de algunos a Portugal y algunas conversiones y confiscación de bienes. Asimismo, se demostró la posibilidad de usar el antisemitismo en la lucha de bandos nobiliarios urbanos por el control del poder municipal.

El impacto del pogrom de 1391 en Portugal es la llegada de judíos y conversos castellanos, que pronto vuelven a judaizar. El móvil del asalto a las juderías es el robo por la asociación de la mentalidad cristiana del judío a la riqueza agravada por la incapacidad de la mayoría cristiana de castigar a los cristianos por actos de agresión a los judíos. La justicia real cuando se produce es rápida y a veces el Rey se marcha de Lisboa o destierra a los agresores a Ceuta ${ }^{16}$.

Cortes de los Antiguos Reinos de León y Castilla. Cortes de 1371, págs. 203-214; Cortes de 1377, págs. 276-282; 1380, págs. 305-309. Montes Romero-CAMACHO, 1., "Antisemitismo sevillano en la Baja Edad Media. El pogrom de 1391", Actas del III Congreso de Historia Medieval Andaluza. La sociedad medieval andaluza. Jaén 1984, págs, 57-76. RAmírez de ARELLANO, R., "Matanza de judíos en Córdoba», 1391, BRAH, 38, 1901, págs. 294-311.

16 Parejo Delgado, M. J., Baeza y úbeda en la Baja Edad Media, ob. cit. Sevilla, págs. $760-$ 762. Mitre Fernández, E., «Los judíos y la corona de Castilla en el tránsito al siglo XV", Cuadernos de Historia, III, 1969, págs. 345-368. «Crisis de subsistencias y conflictividad social en 
Durante el siglo XV continúan manteniéndose las leyes que separan a los judíos de los cristianos (Ordenamiento de Valladolid de 1405), pero se les trata peor que a los mudéjares, cuya convivencia es más fácil. Las disposiciones de doña Catalina de 1412 ampara a los que se conviertan al cristianismo y prohíbe a los cristianos entrar en las juderías, tomar alimentos elaborados por ellos, asistir a sus bodas, y ser testigos. Asimismo, se les prohíbe ejercer de arrendadores, recaudadores, almojarifes, usar telas costosas, y ser herreros. No obstante en 1425, aunque menguada, continúa existiendo una pequeña comunidad en Úbeda que pagaba el impuesto de las 30 monedas. En Portugal hay disposiciones semejantes, así en 1412 se castiga al judío de más de 15 años que va a la zona cristiana con multas de 5.000 libras y prisión. Más tarde don Duarte permite a los cristianos tanto hombres como mujeres entrar en las juderías pero siguen prohibidas las relaciones sexuales entre miembros de las dos comunidades religiosas. Juan I de Portugal prohíbe a las mujeres trabajar en la vendimia y sementera de las propiedades judías. No obstante, las cartas de perdón encontradas en los Protocolos Notariales nos indican cómo con cierta frecuencia la norma era trasgredida, alegando muchas mancebas no conocer el credo religioso de su amante e incluso algunos cristianos hablan de que la violación de las judías está justificada por ser estas mujeres, objeto de gozos inferiores y fáciles. No obstante, los judíos portugueses viven una situación de privilegio si se les compara a los castellanos, ya que hay pocos levantamientos contra las juderías salvo en caso de robo.

La crisis de subsistencia de 1462-1463, la lucha de bandos entre Cuevas y Molinas que finaliza con el fracaso de los Cuevas en 1464 que pierden el Alcázar en favor del bando rival y les obliga a retirarse a Bedmar y la deposición de Enrique IV projudío, provocan algunos motines en la ciudad de Úbeda, donde los Molina - antisemitas-controlan el Cabildo. Las Actas Capitulares de 1461-1463 nos informan progresivamente de la falta de pan y alimentos que vive Úbeda y de las medidas dictadas por el Cabildo para solucionarlo. En diciembre de 1461 el concejo tiene problemas para recaudar las tercias del pan. En junio de 1462 a la falta de pan se une la de carne.

Úbeda, XV-xV|II’, Estudios sobre Úbeda I. Úbeda 1990, págs. 23-26, en colaboración con Adela Tarifa Fernández. EsCABIAS, P., Crónica del Condestable Miguel Lucas de Iranzo, capít. XXXVII. Madrid 1940. LADERO QUESADA, M. A., «Los judeoconversos andaluces en el siglo XV», Actas del III Congreso de Historia Medieval de Andalucía. Jaén 1984, págs. 27-56. AM, Úbeda 1481, abril, 4. Valladolid, leg. $2, n .{ }^{\circ} 41$. 
El Cabildo trata de fijar los precios a los que ha de venderse la libra de carne, la de carnero a 11 maravedíes y la de vaca a siete. Para asegurar el abastecimiento de cereal a úbeda se dictan varias medidas como prohibir a los dueños de las vacas y bueyes que dañen las heredades de vides y panes, que la alhóndiga sea franca y que el pan que se venda fuera pague alcabala. Las campañas del condestable Iranzo, protector de los judíos contra Granada, contribuyen a agudizar el problema del abastecimiento de la ciudad. En 1464 los Molina se hacen con el control del Alcázar y el precio del trigo y de la cebada alcanza precios de 330 y 150 maravedíes por fanega, hecho que provoca los asaltos a algunas juderías como las de Úbeda donde gana el bando antisemita de los Molina y Jaén donde se intenta asesinar al condestable Iranzo, protector de los judíos. El antisemitismo continúa en la década de los setenta (1473), provocando desórdenes en Córdoba, Úbeda y Baeza. La crisis alimenticia agravada por las luchas contra Granada - conquistas de Cambil, Arenas, etc.- y las razzías granadinas contra Santiago e Higuera de Martos endurecen la situación del Común.

El pogrom de 1473 es especialmente virulento en las zonas que contaban con defensores del bando enriqueño benefactor de los judíos a los que permite el comercio sin límites y los préstamos no usureros. En Jaén es asesinado el condestable Miguel Lucas de Iranzo y en Úbeda son saqueadas las casas de los conversos.

Los años de 1482-1484 son el comienzo de una inestabilidad en las relaciones entre judios y cristianos en Portugal, produciéndose disturbios en Lisboa y Oporto; hecho que hay que relacionar con las epidemias de peste. En 1481 un documento conservado en el Archivo Municipal de Úbeda determina cómo las autoridades locales tratan de aplicar la normativa dada en las Cortes de Toledo de 1480 sobre la convivencia entre judíos y moros «de las que los vecinos tienen mucho agrauio", por lo cual se toman varias medidas; que vivan en lugares apartados, que tengan sus propias sinagogas, que adquieran los solares para ello a precios razonables tasados por dos personas, una judía y otra cristiana, que vivan en sus aljamas, e «no se mesclen con los cristianos sopena de perder sus bienes», y finalmente se les da un plazo de dos años una vez obtenidos los solares para edificar las sinagogas si no las hacen en dichos lugares, pierden el terreno.

... Ordenamos e mandamos que todos los judios e moros de todo e qualesquier cibdades e villas e logares destos nuestros rreynos... tengan sus juderias e distantes e apartados... tendemos nombrar y enbiar personas fiables para que faga el dicho apartamiento sunnalado los suelos e casas e sytios donde buenamente pueden bivir e contratar en sus oficios con las gentes e sy en los logares donde asy les semalare non tomaren 
los judios xinogas e los moros mesquitas mandamos a las dichas personas que asy deputaremos para ello que eso mesmo dentro delas tales ciruytos los sennalen otros tantos e tomamos suelos e casas para que fagan los judios xinogas... que de las xinogas... que tenian primero non se aprovechen dendo en adelante para a quellos usos e los quales dichos judios e moros por la presente damos licencia e facultad para que puedan vender e vendan a quierquesyeren las xinogas e mesquitas que dexa$\operatorname{ran} \ldots \gg$

«... Mando que la dicha ley sea executada e trayda a deuido efecto, pues el complimiento della rrendunde en seruicio de Dios... e confiando de vos el dicho Garcia Fernández Manrrique del mi consejo que bien e fiel e deligentemente faredes lo que por mi vos fuere mandado... vos encomiendo e cometo la esecucion de la dicha ley en las cibdades e villas e lugares de yuso contenidos porque vos mando que luego vayades a la cibdad de Jahen e a la cibdad de Ubeda e a la cibdad de Baeca e a la cibdad de Andujar ea los otros lugares de sus tierras e obispados e a cada uno dellos e a los otros lugares que vos entendieredes que cumplen donde oy biuen judios e moros e qualesquier dellos tomedes e juntedes con uos las personas que segund el thenor e firma dela dicha ley and deentender en el sennalarles los sytios e lugares para las sygnogas e mesquitas e casas e solares en que han de beuir...».

Entre 1483 y 1485 son expulsados los judíos de Andalucía, quedando tan menguada su población que quedan pocos testimonios de ello. En Úbeda sabemos de !a existencia de Natan Narboy en 1489, un mercader que vino a rescatar a su hijo, cautivo, por lo que debió solicitar al concejo licencia de dos meses para llevárselo, de un mercader Sunsi Abraham, que registró en escritura dos esclavos moros por valor de 2.500 maravedíes y por último del rabino Abraham, físico del adelantado para que las ciudades desde Úbeda a Medina no cobren derechos por su cuerpo, pues murió en aquella ciudad.

La expulsión de los judíos castellanos en 1492 les hace emigrar a África, Portugal y Levante. Siendo comunicado a los concejos andaluces, Úbeda el 31 de marzo, según consta en el Archivo Municipal, pero ya muchos se habían convertido y en su mayoría habían emigrado ${ }^{17}$.

Así, pues, la comunidad judía en la Úbeda bajomedieval, aunque no fue muy numerosa, apenas alcanzó el 1,5 por 100 del total de la población,

17 Pimienta, M. J., ob. cit., pág. 446. Parejo Delgado, M. J., Baeza y Úbeda en la Baja Edad Media. Sevilla, pág. 779. AM, Ubeda, leg. $5, n .^{\circ} 48,1492$, abril, 23. Bel. Bravo, M. Antonia, Los Reyes Católicos y los judíos andaluces (1474-1492), Granada 1989. Universidad. Granada 1989. SUÁREZ FERNÁNDEZ, L., Documentos acerca de la expulsión de los judios. Valladolid 1964. CANtera Montenegro, E., "Los judíos en la Edad Media hispana», Cuadernos de Investigación Medieval, n. ${ }^{\circ}$ 5. Madrid 1986 
tuvo una cierta influencia política en la ciudad al gozar primero de la protección real y de los nobles del bando de los Cuevas y de su residencia dentro del recinto amurallado, hecho que la protegió de las iras del Común y de las razzías granadinas. Su volumen demográfico descendió como el de otras aljamas castellanas bien por la conversión bien por la emigración tras los pogroms sufridos en 1391, 1464 y 1473.

La relación de penitenciados de Úbeda y su término de 1496 indica cómo después de 1391 salvo contadas excepciones la mayoría de los judíos ubetenses o había emigrado o se habían convertido. El volumen de los penitenciados de 1496 conversos así parece demostrarlo. Su nivel económico fue bastante similar al de los labradores y comerciantes enriquecidos. La actitud del Común de Úbeda hacia los judios fue de clara hostilidad, pues ven en ellos no sólo a personas de distinto credo religioso, sino a influyentes comerciantes, labradores y artesanos, protegidos por la pequeña nobleza local. 